\title{
Eksplorasi Jenis-Jenis Ikan di Perairan Danau Lindu Provinsi Sulawesi Tengah
}

\author{
${ }^{1}$ Nurfadilah Rahma, ${ }^{2}$ Manap Trianto \\ ${ }^{1}$ Program Studi Pendidikan Biologi, Universitas Tadulako, Palu, Indonesia \\ ${ }^{2}$ Fakultas Biologi, Universitas Gadjah Mada, Yogyakarta, Indonesia \\ 1'nurfadilahrahma3@gmail.com, ${ }^{2}$ manaptrianto@mail.ugm.ac.id
}

\section{ARTICLE INFO}

\section{Article History:}

Received : 17-09-2018

Revised : 23-11-2018

Accepted : 27-11-2018

Online : $\quad 30-11-2018$

Keywords:

Exploration; Fish; Lindu

Lake; Central Sulawesi

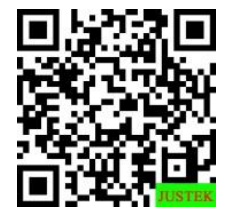

\begin{abstract}
Abstract: Fish are defined as vertebrates that live in water with characteristics of gills that function to take dissolve oxygen from water and fins used for swimming. This research aims to determine the species of fish that exist in Lindu Lake, Central Sulawesi Province. The method used is purposive sampling by using fishing gear net, fishing line and seser. Base on the result of this research was found 10 species of fish consisting of 9 Ordo and 6 Family, namely Oreochromis mossabicus, Oreochromis niloticus, Cyprinus caprio, Anabas testudineus, Osphroneus gourami, Anguilla marmorate, Aplocheilus panchax, Clarias batrachus, Channa striata and Puntius gonionatus.
\end{abstract}

Abstrak: Ikan merupakan hewan bertulang belakang yang hidup di air dengan karakteristik memiliki insang yang berfungsi untuk mengambil oksigen terlarut dari air dan sirip yang digunakan untuk berenang. Penelitian ini bertujuan untuk mengetahui jenis ikan yang terdapat di Perairan Danau Lindu Provinsi Sulawesi Tengah. Metode yang digunakan adalah purposive sampling dengan menggunakan alat tangkap, pancing, dan seser. Berdasarkan hasil penelitian ditemukan 10 jenis ikan yang terdiri dari 9 ordo dan 6 family. Spesies ikan yang di peroeleh yaitu Oreochromis mossambicus, Oreochromis niloticus, Cyprinus carpio, Anabas testudineus, Osphronemus gourami, Anguilla marmorat, Aplocheilus panchax, Clarias batrachus, Channa striata dan Puntius gonionatus.

\section{A. LATAR BELAKANG}

Danau merupakan wilayah dengan peran yang sangat penting dalam menunjang kehidupan manusia, baik dalam bidang perikanan, pertanian atau kebutuhan seharihari (Aflaktur, 2005; Dirham dan Trianto, 2020). Jorgensen (1989) perairan danau adalah bentuk ekosisitem (air tawar) yang menempati porsi di permukaan bumi, sedangkan secara fisik perairan danau dapat dikatakan sebagai tempat yang memiliki ukuran luas dengan komposisi air yang tetap, jernih atau beragam dengan aliran yang mengikuti kondisi lingkungan. Selanjutnya, Wulandari (2006) menjelaskan bahwa danau merupakan wilayah perairan yang masuk dalam kelompok lahan basah serta dikelilingi oleh suatu daratan.

Di alam, danau memiliki fungsi yang sangat penting khususnya dalam sektor ekonomi, misalnya perikanan baik dalam skala tangkap atau budidaya. Selain itu, danau 
juga memiliki fungsi sebagai tempat hidup berbagai macam biodiversitas, salah satunya yaitu ikan (Odum, 1993). Ikan merupakan salah satu organisme yang keberadaannya dipengaruhi oleh kondisi lingkungan perairan. Perubahan kondisi perairan akibat limbah dapat mempengaruhi keberadaan ikan disuatu perairan. Misalnya limbah rumah tangga seperti air detergen, air cucian piring, dan limbah kimia pertanian (Rifai et al., 1983).

Kualitas air Danau Lindu sebagai tempat hidup berbagai jenis ikan sangat tergantung pada kondisi lingkungan seperti suhu, hara, oksigen terlarut, dan beberapa parameter lainnya (Sawestri et al., 2013). Terdapat beberapa spesies ikan introduksi yang hidup di Danau Lindu yaitu gurame (Osphronemus gourami), ikan mas (Cyprinus carpio), sepat (Trichogaster pectoralis), mujaer (Oreochromis mossambicus), tawes (Puntius javanicus), dan lele (Clarias batrachus). Sedangkan jenis ikan asli Danau ini yaitu sidat (Anguilla sp.) dan ikan Xenopoecilus sarasinorum. Ikan Xenopoecilus sarasinorum merupakan jenis ikan endemik dari Danau Lindu, namun saat ini keberadaan ikan tersebut jarang ditemui. Tahun 1996 masuk pada daftar jenis ikan terancam punah (endangered) pada IUCN Red List of Threatened Animals (Lukman dan Ridwansyah, 2003). Penelitian ini bertujuan untuk mengetahui jenis ikan di Perairain Danau Lindu, Provinsi Sulawesi Tengah.

\section{B. METODE PENELITIAN}

Jenis penelitian yang digunakan adalah penelitian deskriptif eksploratif dan teknik yang digunakan dalam pengambilan sampel yaitu menggunakan teknik purposive sampling. Area penelitian dibagi menjadi 6 stasiun yaitu pada outlet, intlet, bagiaan tengah danau, pemukiman, peternakan dan perkebunan. Pengambilan sampel ikan dilakukan dengan menggunakan jaring, pancing, dan seser.

Penangkapan ikan dilakukan dengan menggunakan jaring. Kemudian, ikan yang telah tertangkap akan diidentifikasi berdasarkan jenisnya di Laboratorium Pendidikan Biologi, FKIP, UNTAD. Selanjutnya melakukan pengukuran kondisi fisik-kimia Perairan Danau Lindu Kabupaten Sigi Provinsi Sulawesi Tengah, dengan cara melakukan pengukuran kondisi fisik- kimia perairan. Parameter yang diukur di lapangan adalah suhu dengan menggunakan thermometer, salinitas dengan salinometer dan $\mathrm{pH}$ air dengan $\mathrm{pH}$-meter.

\section{HASIL DAN PEMBAHASAN}

Danau Lindu terletak di Kecamatan Lindu Kabupaten Sigi Provinsi Sulawesi Tengah. Jarak tempuh dari ibu kota Provinsi Sulawsi Tengah (Palu) $\pm 123 \mathrm{~km}$. Danau Lindu

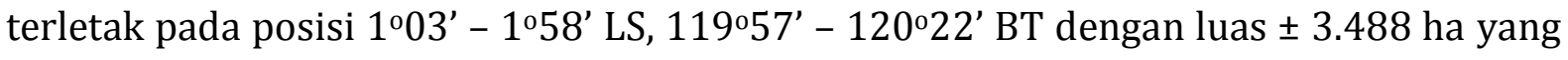
terletak dalam wilayah Taman Nasional. Luas Taman Nasional Lore Lindu berdasarkan Surat Keputusan Mentri Kehutanan dan Perkebunan No. 464/Kpts-II/1999 tanggal 23 Juni 1999, dikukuhkan dengan luas kawasan 217.991, 18 ha. Cagar biosfer Lore Lindu terletak di jantung Pulau Sulawesi. Secara geografis terletak pada posisi 119090' 120¹6’ BT dan 18' - 1³’ LS. Sebagai Cagar Biosfer, kawasan ini memiliki tiga bagian utama, yaitu area inti, zona penyangga (buffer zone), dan area transisi. Area inti (core 
area) Cagar Biosfer Lore Lindu adalah Taman Nasional Lore Lindu (TNLL) （Soedjito, 2004).

Tabel 1. Kondisi Fisik-Kimia Lingkungan

\begin{tabular}{cc}
\hline Parameter & $\boldsymbol{\Sigma}$ \\
\hline Suhu Lingkungan $\left({ }^{\circ} \mathrm{C}\right)$ & 27,32 \\
Suhu Air $\left({ }^{0} \mathrm{C}\right)$ & 26,20 \\
$\mathrm{pH}$ & 7,8 \\
Kadar Oksigen Terlarut $(\mathrm{mg} / \mathrm{l})$ & 6,2 \\
Salinitas $(\% 0)$ & 0 \\
Kecerahan $(\mathrm{m})$ & 1,30 \\
\hline
\end{tabular}

Berdasarkan hasil penelitian yang dilakukan pada enam stasiun pengamatan, secara keseluruhan ditemukan 10 jenis ikan yang terdiri dari 9 Ordo, 6 Family yaitu ikan mujair (Oreochromis mossambicus) tergolong dalam ordo Perchomorphi, ikan nila (Oreochromis niloticus) tergolong dalam ordo Perciformes dan termasuk family yang sama yaitu Cichlidae ikan mas (Cyprinus carpio) tergolong dalam ordo Cypriniformes, ikan tawes (Puntius gonionatus) tergolong dalam ordo Ostariophysi, ikan lele (Clarias batrachus) tergolong dalam odo Siluriformes dan tergolong dalam family yang sama yaitu Cyprinidae, ikan betok (Anabas testudineus) dan ikan gurami (Osphronemus gourami) tergolong dalam ordo yang sama yaitu Labyrinthyci dan juga tergolong dalam family yang sama yaitu Anabantidae, ikan sidat (Anguilla marmorat) tergolong dalam ordo Apodes dan tergolong family Anguillidae, ikan kepala timah (Aplocheilus panchax) tergolong dalam ordo Cyprinodontiformes dan tergolong family Aplocheilidae, ikan gabus (Channa striata) tergolong dalam ordo Labyrinthyci dan termasuk dalam family Ophyocephalidae.

Tabel 2. Jenis ikan di Perairan Danau Lindu, Provinsi Sulawesi Tengah

\begin{tabular}{|c|c|c|}
\hline Ordo & Famili & Spesies \\
\hline Perchomorphi & Cichlidae & Oreochromis mossambicus \\
\hline Perciformes & & Oreochromis niloticus \\
\hline Cypriniformes & Cyprinidae & Cyprinus carpio \\
\hline Ostariophysi & & Puntius gonionatus \\
\hline Siluriformes & & Clarias batrachus \\
\hline Labyrinthyci & Anabantidae & $\begin{array}{l}\text { Anabas testudineus } \\
\text { Osphronemus gourami }\end{array}$ \\
\hline Apodes & Anguillidae & Anguilla marmorat \\
\hline Cyprinodontiformes & Aplocheilidae & Aplocheilus panchax \\
\hline Labyrinthyci & Ophyocephalidae & Channa striata \\
\hline
\end{tabular}

Stasiun I (outlet) yang merupakan tempat keluarnya air. Pada daerah ini keadaan arus air sangat deras. Pada stasiun ini terdapat 2 spesies yaitu ikan mujair (Oreochromis mossambicus) dan ikan nila (Oreochromis niloticus). Jenis-jenis ikan tersebut adalah jenis yang tahan terhadap lingkungan ekstrim di perairan tawar khususnya perairan danau. Jenis ikan yang diperoleh pada stasiun terbilang sedikit dikarenakan arus air yang sangat deras. Selanjutnya, Stasiun II (inlet) merupakan tempat masuknya air. Pada stasiun ini terdapat 6 spesies yaitu ikan mujair (Oreochromis mossambicus), ikan nila (Oreochromis niloticus), ikan mas (Cyprinus carpio), ikan betok (Anabas testudineus), ikan kepala timah (Aplocheilus panchax), ikan tawes (Puntius gonionatus). 
Stasiun III (tengah danau) merupakan daerah yang masih tergolong jarang dijadikan sebagai areal penangkapan ikan oleh nelayan sehingga dapat dikatakan bahwa aktivitas nelayan daerah ini tidak mempengaruhi kehidupan organisme perairan serta kualitas perairan danau. Pada stasiun ini diperoleh 6 spesies yaitu ikan mujair (Oreochromis mossambicus), ikan nila (Oreochromis niloticus), ikan mas (Cyprinus carpio), ikan betok (Anabas testudineus), ikan sidat (Anguilla marmorat) dan ikan tawes

(Puntius gonionatus). Selanjutnya, Stasiun IV (pemukiman) merupakan daerah masyarakat melakukan aktivitas sehari-hari termasuk pula tempat pelelangan ikan. Pada stasiun ini terdapat 8 spesies yaitu ikan mujair (Oreochromis mossambicus), ikan nila (Oreochromis niloticus), ikan betok (Anabas testudineus), ikan gurami (Osphronemus gourami), ikan kepala timah (Aplocheilus panchax), ikan lele (Clarias batrachus), ikan gabus (Channa striata) dan ikan tawes (Puntius gonionatus). Pada stasiun ini diperoleh paling banyak jenis ikan dikarenakan daerah pemukiman sekitaran Danau Lindu kearifan lokal sangat erat sehingga ada wakku tertentu aktifitas masyarakat dikurangi selama 3 bulan guna penyemaian ikan. Pemerintah setempat juga menanam

Hydrilla verticillata di danau sekitar pemukiman dengan harapan kelimpahan dan keanekaragaman jenis ikan di Danau Lindu meningkat.

Stasiun V (peternakan) merupakan daerah danau yang berdekatan dengan tempat masyarakat melakukan aktivitas peternakan berupa beternak bebek dan kerbau. Pada stasiun ini terdapat 4 spesies yaitu ikan mujair (Oreochromis mossambicus), ikan nila (Oreochromis niloticus), ikan kepala timah (Aplocheilus panchax) dan ikan lele (Clarias batrachus). Berdasarkan kondisi fisik dan kimia pada stasiun ini yaitu daerah danau sekitaran peternakan maka sisa makan dan kotoran ternak sebagian ada yang mengalir ke danau sehingga hanya jenis ikan yang tahan terhadap kondisi ekstrim yang dapat bertahan. Selanjutnya, Stasiun VI (perkebunan) merupakan daerah danau yang berdekatan dengan tempat masyarakat melakukan aktivitas pertanian berupa tanaman cokelat (Theobrema cacao) sehingga pestisida yang digunakan mengalir didanau ketika hujan. Pada stasiun ini terdapat 6 spesies yaitu ikan mujair (Oreochromis mossambicus), ikan nila (Oreochromis niloticus), ikan gurami (Osphronemus gourami), ikan kepala timah (Aplocheilus panchax), ikan lele (Clarias batrachus) dan ikan gabus (Channa striata).

Berdasarkan hasil pengukuran terhadap suhu lingkungan pada keenam stasiun diperoleh yaitu pada stasiun I adalah $27,25{ }^{\circ} \mathrm{C}$, stasiun II $27,75{ }^{\circ} \mathrm{C}$, stasiun III $27,65{ }^{\circ} \mathrm{C}$, stasiun IV 27,70 ${ }^{\circ} \mathrm{C}$, stasiun V 27,75 ${ }^{\circ} \mathrm{C}$ dan stasiun VI adalah 27,85 ${ }^{\circ} \mathrm{C}$. Untuk daerah tropis suhu ini masih dalam batas toleran dan tidak membahayakan kehidupan ikan. Seperti yang dijelaskan Mamu (2007) bahwa suhu optimum kehidupan ikan dan organisme adalah pada kisaran $25-30,5{ }^{\circ} \mathrm{C}$. $\mathrm{pH}$ yang diperoleh dari hasil pengukuran pada setiap stasiun pengamatan yaitu pada stasiun I adalah 7,6, stasiun II 7,9, stasiun III 8,1, satsiun IV 7,7, stasiun V 7,8 dan stasiun VI adalah 7,9. Menurut baku mutu air dalam peraturan pemetintah RI nomor 20 tahun 1990 yaitu berada antara 6,0 sampai 9,0, menunjukan baha $\mathrm{pH}$ perairan Danau Lindu masih dalam taraf normal untuk mendukung kehidupan biota perairan. Kadar oksigen terlarut yang diperoleh dari hasil pengukuran pada ke enam stasiun yaitu 6,2 mg/l. Menurut buku mutu air untuk golongan C, oksigen terlarut ditetapkan $>3 \mathrm{mg} / \mathrm{l}$ (Nurdin, 2000; Hartina dan Trianto, 
2020). Kandungan oksigen terlarut yang dapat mendukung perkembangan organisme air nilainya harus lebih besar dari $5 \mathrm{mg} / \mathrm{l}$. Oksigen terlarut sangat penting bagi pernapasan ikan dan organisme akuatik lainnya (Odum, 1993; Trianto et al., 2020). Salinitas yang diperoleh dari hasil pengukuran pada ke enam stasiun yaitu 0 \%o. Salinitas perairan Danau Lindu masih dalam taraf normal untuk mendukung kehidupan ikan dan organisme perairan lainnya. Seperti yang dijelaskan Soetjipta (1993) bahwa kandungan garam atau salinitas air tawar ialah kurang dari 0,5\%o. Kecerahan yang diperoleh dari hasil pengukuran pada setiap stasiun pengamatan yaitu pada stasiun I adalah 1 , stasiun II 0,5, stasiun III 3,35, satsiun IV 1, stasiun V 1 dan stasiun VI adalah 1 m. Nurdin (2000) membagi kondisi perairan berdasarkan nilai transparansi, yaitu perairan keruh (0,25-1,00 meter); perairan sedikit keruh (1,00-5,00 meter); perairan jernih ( $>5$ meter). Berdasarkan hal tersebut maka perairan Danau Lindu stasiun I, II, IV, V, VI tergolong perairan keruh dan Stasiun III tergolong dalam perairan sedikit keruh karena stasiun III yaitu tengah danau.

Berdasarkan hasil di atas ikan yang tergolong dalam ikan endemik yaitu ikan sidat (Anguilla marmorat) sedangkan yang tergolong dalam ikan introduksi yaitu ikan mujair (Oreochromis mossambicus), ikan nila (Oreochromis niloticus), ikan mas (Cyprinus carpio), ikan betok (Anabas testudineusI), ikan gurami (Osphronemus gourami), ikan kepala timah (Aplocheilus panchax), ikan lele (Clarias batrachus), ikan gabus (Channa striata) dan ikan tawes (Puntius gonionatus) hal ini sesuai dengan yang dikatakan Lukman dan Ridwansyah (2003). Penelitian sebelumnya yang dilakukan Zainal (2011) tentang Kelimpahan Jenis Ikan Berdasarkan Alat Tangkap yang Digunakan di Perairan Danau Lindu Kecamatan Lindu Kabupaten Sigi Provinsi Sulawesi Tengah memperoleh 10 jenis ikan. Kemudian dalam jangka waktu 7 tahun kembali dilakukan penelitian mengenai Eksplorasi Jenis Ikan Perairan Danau Lindu Kabupaten Sigi Provinsi Sulawesi Tengah juga mendapatkan 10 jenis ikan namun 1 jenis ikan pada penelitian sebelumnya berbeda yaitu ikan sidat putih hijau (Anguilla bicolor) yang tidak didapatkan oleh penelitian saat ini. Ikan ini merupakan salah satu ikan endemik Danau Lindu yang kini sangat sulit didapatkan. Tidak diperolehnya ikan tersebut dikarenakan faktor fisik kimia lingkungan yaitu waktu pelaksanaan penelitian yang terbatas, kearifan lokal yang sedang berlangsung sehingga keterbatasan peneliti untuk menangkap ikan dan kecerahan danau pada saat ini berkurang di bandingkan penelitian sebelumnya.

\section{SIMPULAN}

Penelitian yang dilakukan terhadap Eksplorasi Jenis-Jenis Ikan Perairan Danau Lindu Kabupaten Sigi Provinsi Sulawesi Tengah ditemukan 10 jenis ikan yaitu ikan mujair (Oreochromis mossambicus), ikan nila (Oreochromis niloticus), ikan mas (Cyprinus carpio), ikan betok (Anabas testudineus), ikan gurami (Osphronemus gourami), ikan sidat (Anguilla marmorat), ikan kepala timah (Aplocheilus panchax), ikan lele (Clarias batrachus), ikan gabus (Channa striata) dan ikan tawes (Puntius gonionatus). 


\section{REFERENSI}

Aflakur. (2005). Pakan Ikan. Yogyakarta: Fakultas Peternakan dan Perikanan Universitas Negeri Yogyakarta.

Dirham, dan Trianto, M. (2020). Stomach Content Analysis of Tilapia Fish (Oreochromis mossambicus) in Talaga Lake Waters Donggala Regency. Jurnal BIO-EDU, 5(3), 118-128.

Hartina, S, dan Trianto, M. (2020). Diversity of Zooplankton in Lindu Lake Waters Central Sulawesi Province. Jurnal BIO-EDU, 5(3), 129-139.

Jorgensen. (1989). Fresh Water Invertebrates of the United States. Second edition. John WiF198y and Sons. Inc. New York.

Lukman dan Ridwansyah. (2003). Kondisi daerah tangkapan dan ciri morfometri Danau Lindu. Oseanologi \& Limnologi Indonesia. 35: 11-20.

Mamu, H.D. 2007. Keanekaragaman dan Distribusi Ikan Air Tawar di Perairan Danau Talaga Kabupaten donggala Sulawesi Tengah. Technological And Provesional Skills Development Sector Project (TPSDP)- Batch Universitas Tadulako. Palu

Nurdin. E. 2000. Potensi Pengembangan Perikanan Di Situ Pondok Cina Universitas Indonesia Depok. Makala Jurnal Penelitian Universitas Indonesia Edisi Sains dan Tekhnologi. Lembaga Penelitian U.I/Depok.

Odum, E.P. (1993). Dasar-dasar Ekologi Edisi Ketiga. (Terj. Thahjono The Academy of Natural Science of Phyladelphia). Jogyakarta: Gadjah Mada Pres.

Pradhana, A. I, Mudjiono, G., dan Karindah S. (2014). Kenakeragaman Serangga dan Laba-laba pada Pertanaman Padi Organik dan Konvensional. Jurnal Hama dan Penyakit Tumbuhan, 2(2), 58-66.

Pratama, A, dan Trianto, M. (2020). Diversity of Lichen in Mangrove Forest of Tomili Village Parigi Moutong Regency. Jurnal BIO-EDU, 5(3), 140-150.

Rifai, S.A., Nurdawati \& Nasution. (1983.) Biologi Perikanan. Edisi Pertama. Jakarta:Departemen Pendidikan dan Kebudayaan.

Saanin, H. (1984). Taksonomi dan Kunci Identifikasi Ikan I dan II. Bogor: Bina Cipta

Sawestri, S., Samuel \& N. K. Suryati. (2013). Composition and diversity of phytoplankton in Lake Lindu, Central Sulawesi. 4th International Conference on Biology, Environment and Chemistry. IPCBEE vol. 58 (2013). LACSIT Press Singapore.

Soedjito, H. 2004. Panduan Cagar Biosfer di Indonesia. Bogor: LIPI.

Soetjipta. 1993. Dasar-Dasar Ekologi Hewan. Yogyakarta: Fakultas Biologi UGM .

Trianto, M, Kaini, Saliyem, Warsih, E, dan Winarsih. (2020). Keanekaragaman Serangga Polinator pada Tanaman Nanas (Ananas comosus (L.) Merr.) di Desa Bincau. Jurnal Penelitian Science dan Pendidikan, 9(2), 154-162.

Wulandari. (2006). Kehidupan dalam setetes air. Bandung: ITB Press.

Zainal, S. (2011). Kelimpahan Jenis Ikan Berdasarkan Alat Tangkap yang Digunakan di Perairan Danau Lindu Kecamatan Lindu Kabupaten Sigi Provinsi Sulawesi Tengah. Skripsi. Fakultas Keguruan dan Ilmu Pendidikan. Palu: UNTAD. Tidak diterbitkan. 